\title{
Endoscopy-Assisted Versus Open Tissue Expander Placement in Plastic and Reconstructive Surgery: A Meta-Analysis
}

\author{
Chen Dong \\ Xijing Hospital, Fourth Military Medical University https://orcid.org/0000-0002-1189-5458 \\ Liwei Dong \\ Xijing Hospital, Fourth Military Medical University \\ Zhou Yu \\ Xijing Hosital, Fourth Military Medical University \\ Xianjie Ma ( $\square$ majing@fmmu.edu.cn ) \\ Xijing Hospital, Fourth Military Medical University https://orcid.org/0000-0001-5462-0895
}

\section{Research}

Keywords: Tissue expansion, Tissue expansion devices, Endoscopes, Plastic surgery, Meta-analysis

Posted Date: March 31st, 2021

DOI: https://doi.org/10.21203/rs.3.rs-365596/v1

License: (c) (i) This work is licensed under a Creative Commons Attribution 4.0 International License. Read Full License 


\section{Abstract \\ Background}

Tissue expansion can solve the problem of tissue deficiency in plastic and reconstructive surgery, but it is a lengthy process with many possible complications. This meta-analysis aimed to determine whether endoscopy-assisted expander placement could decrease complications and shorten treatment time.

\section{Methods}

A literature search was performed in eight databases from their inception dates up to November 22, 2020, to identify clinical studies on endoscopy-assisted and/or open tissue expander placement in plastic and reconstructive surgery. Risk difference (RD) and weighted mean difference (WMD), along with the $95 \%$ confidence intervals $(95 \% \mathrm{Cl})$, were calculated to compare the pooled results.

\section{Results}

Seven studies met the inclusion criteria. Of the 759 patients, 194 received endoscopy-assisted expander placement and 565 patients received open expander placement. Overall complication rate was significantly lower in the endoscopy-assisted group than in the open expander group (pooled RD $-0.28,95 \% \mathrm{Cl},-0.38$ to $-0.18, p<0.001$ ). Subgroup analysis showed significantly lower incidence rates for haemotoma, infection, and dehiscence, but not for extrusion and deflation. The endoscopy-assisted group also had significantly shorter surgery time (WMD, -13.97 $\min ; 95 \% \mathrm{Cl},-15.85$ to -12.08 minutes, $p<0.001$ ), hospital stay (WMD, -16.88 hours; $95 \% \mathrm{Cl},-24.36$ to -9.40 hours, $\mathrm{p}<0.001$ ), and time to full expansion (WMD, -27.54 days; $95 \% \mathrm{Cl},-38.85$ to -16.24 days, $\mathrm{p}<0.001$ ).

\section{Conclusions}

Endoscopy-assisted expander placement may help lower the risk of complications such as haemotoma, infection, and dehiscence, and also reduce surgery time, hospital stay, and time to full expansion. (PROSPERO: CRD42021226116)

\section{Introduction}

Severe tissue deficiency can pose major challenges during plastic and reconstructive surgery for conditions such as battlefield wounds, scar deformity of large areas, and superficial organ deformation. ${ }^{1-3}$ Traditional methods such as skin graft, local flap, distant flap, regional flap, and free-tissue transfer are all at the expense of tissue loss in donor areas and possible new damage and scarring. ${ }^{4}$ Tissue expansion, introduced by Neumann, Radovan, Austad, and other scholars, has many obvious advantages in such situations and has therefore become one of most popular techniques in plastic and reconstructive surgery. ${ }^{5-7}$

While the tissue expansion technique can generate extra skin and soft tissue of the exact color and texture necessary for reconstruction in a specific area, without risk of inducing defect or scarring in a donor area, ${ }^{2,8}$ the lengthy process and the high complication rate are important disadvantages. In previous studies, the complication rate of tissue expansion has ranged from 4-63\% (mean, $17 \%) .{ }^{9}$ The expansion time of several weeks or months also entails much inconvenience and pain to patients. Traditionally, expanders were placed through an incision made at the edge of the defect. These incisions needed to be of sufficient length to allow unimpeded vision during dissection of the pocket. ${ }^{10}$ The large surgical incisions and the delayed injection of expander resulted in longer hospital stay. With the introduction of endoscopy, it became possible to place the expander under direct visualization through a small incision. Many plastic surgeons believe that endoscopic placement of the expander reduces complications and shortens surgery time and the time to full expansion and, hence, hospital stay. ${ }^{8,11-16}$ However, to date, no evidence-based studies have evaluated the benefits of endoscopy-assisted expander placement versus the traditional techniques (open expander placement). This meta-analysis aimed to determine whether endoscopy-assisted expander placement can lower the complication rate of tissue expansion and shorten treatment time.

\section{Methods}

This study followed the principles of Preferred Reporting Items for Systematic Reviews and Meta-Analyses (PRISMA). The protocol for this meta-analysis is available in PROSPERO (CRD42021226116).

\section{Search Strategy}


On November 22, 2020, we searched the online databases of PubMed, EMBASE, Web of Science, Cochrane Library, China National Knowledge Infrastructure Database (CNKI), China Science and Technology Journal Database (CSTJ), Wanfang Data, and SinoMed for studies that evaluated endoscopy-assisted expander placement and/or open expander placement in plastic and reconstructive surgery. The search was conducted using the medical subject headings terms tissue expansion, tissue expansion devices, and endoscopy, or related free terms. There was no restriction on the time of publication. The search strategy is reported in detail in Supplement 1.

\section{Study Selection Criteria}

Studies were eligible for inclusion in this meta-analysis only if 1) they were in English or Chinese languages; 2) they were randomized controlled trials (RCT) or retrospective cohort studies; 3 ) patients underwent tissue expansion by the open and/or endoscopic method; and 4) complication rate was reported, along with/without other outcomes such as surgery time, hospital stay, and time to full expansion. Complications of expander placement were defined as abnormalities of soft tissue around the expander between expander placement and removal; thus, the complications included seroma, haemotoma, infection, wound dehiscence, extrusion, deflation, or failure of expansion.

Case reports or series, reviews, letters, animal/in vitro studies, and duplicated publications were excluded.

\section{Risk-of-Bias Assessment}

The methodological quality of studies was assessed independently by two researchers (CD and ZY); disagreements were resolved by discussion or by consultation with a third researcher (X-JM). The Cochrane risk-of-bias tool (RoB) was used to evaluate RCTs. ${ }^{17}$ Only if all key domains showed low risk of bias was the RCT classified as high quality; if any one key domain showed high risk of bias, the RCT was classified as low quality. ${ }^{17}$ The Newcastle-Ottawa scale (NOS) was used to evaluate the quality of cohort studies ${ }^{18}$; a score $\geq 7$ stars was considered to indicate low risk of bias. ${ }^{19}$

\section{Data Extraction}

Two researchers (CD and ZY) independently reviewed the selected publications and recorded the following: name of first author, year of publication, language of article, country, mean patient age and other characteristics, study design, number of patients receiving endoscopic expander placement and open expander placement surgery time, hospital stay, time to full expansion, follow-up time, and total and individual complication rates. Disagreements between the researchers were resolved by discussion.

\section{Statistical Analysis}

We used the random effects model for the meta-analysis. The risk difference (RD) was calculated for complication rates, and the weighted mean difference (WMD) for other outcomes; the 95\% confidence intervals (95\% Cl) were also calculated. The Mantel-Haenszel chi-square test was used to evaluate heterogeneity, and the $R$ statistic was used to assess its impact on the meta-analysis. In this study, $p<0.10$ or $R>50 \%$ was considered to indicate significant heterogeneity. ${ }^{20}$ Subgroup analysis was performed to determine the influences of different complications (haemotoma, infection, extrusion, dehiscence, and deflation) on the pooled effects. Sensitivity analysis was performed by excluding studies one by one and observing whether the new pooled result changed significantly (i.e., whether the new point estimate was outside the $95 \% \mathrm{Cl}$ of the original total pooled effect). ${ }^{21}$ Publication bias was assessed by funnel plots, Egger's regression test, and Begg's rank test. ${ }^{22-24}$ Meta-regression analysis, with restricted maximum-likelihood, was used to evaluate associations between treatment effect (RD of total complications) and study characteristics (research type, article language, study population). ${ }^{25}$ Review Manager 5.4 software (The Cochrane Collaboration, 2020) and Stata 15 software (StataCorp LLC, 2017) were used for data analysis. All tests were two-tailed, and statistical significance was at $p<0.05$ unless otherwise specified.

\section{Results}

\section{Study Selection}

The initial database search identified a total of 484 publications (PubMed, 84; EMBASE, 74; Web of Science, 74; Cochrane library, 14; CNKI, 28; CSTJ, 15; Wanfang Data, 17; and SinoMed, 178). After screening titles and abstracts, 443 studies were eliminated. The full texts of the remaining 41 studies were read, and 7 studies that met all eligibility criteria were finally included in this meta-analysis. Figure 1 shows the study selection process.

\section{Study Characteristics}

Of the seven included studies, two were RCTs and five were retrospective cohort studies. ${ }^{8,11-16}$ The studies were from China, USA, Russia, and Iran. Four articles were in English and three were in Chinese. The seven studies included a total of 759 patients and more than 1142 
expanders. While 194 patients received endoscopy-assisted expander placement, 565 patients received open expander placement. Table 1 lists the characteristics of the included studies and the follow-up durations.

Table 1

Characteristics of the Included Studies

\begin{tabular}{|c|c|c|c|c|c|c|c|c|c|}
\hline $\begin{array}{l}\text { First } \\
\text { Author, } \\
\text { Year, } \\
\text { Country }\end{array}$ & $\begin{array}{l}\text { Mean Age } \\
\text { (years) }\end{array}$ & $\begin{array}{l}\text { Number } \\
\text { of } \\
\text { Females } \\
\mathrm{n}(\%)\end{array}$ & Indication & $\begin{array}{l}\text { Study } \\
\text { Design }\end{array}$ & $\begin{array}{l}\text { Study } \\
\text { Language }\end{array}$ & $\begin{array}{l}\text { Total } \\
\text { Number of } \\
\text { Patients } \\
\text { (Expanders) }\end{array}$ & $\begin{array}{l}\text { Number of } \\
\text { Patients } \\
\text { (Expanders) } \\
\text { Receiving } \\
\text { Endoscopic } \\
\text { Technique }\end{array}$ & $\begin{array}{l}\text { Number of } \\
\text { Patients } \\
\text { (Expanders) } \\
\text { Receiving } \\
\text { Open } \\
\text { Technique }\end{array}$ & $\begin{array}{l}\text { Follow-Up } \\
\text { Mean } \\
\text { Time } \\
\text { and Rate }\end{array}$ \\
\hline $\begin{array}{l}\text { Toranto, } \\
2007, \\
\text { USA }\end{array}$ & $\begin{array}{l}23.1 \\
\text { (Open) } \\
34.9 \\
\text { (Endo) }\end{array}$ & $\begin{array}{l}\text { Not } \\
\text { specified }\end{array}$ & $\begin{array}{l}\text { Giant } \\
\text { congenital } \\
\text { nevi, trauma, } \\
\text { burns, } \\
\text { chronic } \\
\text { wounds, and } \\
\text { hernias }\end{array}$ & RCS & English & $69(202)$ & $18(75)$ & 51 (127) & $\begin{array}{l}\text { Expansion } \\
\text { duration } \\
\text { (One } \\
\text { patient } \\
\text { was lost } \\
\text { to follow- } \\
\text { up) }\end{array}$ \\
\hline $\begin{array}{l}\text { Sharobaro, } \\
2008, \\
\text { Russia }\end{array}$ & $\begin{array}{l}25.1 \\
\text { (Endo) }\end{array}$ & $\begin{array}{l}18 \\
(66.7) \\
\text { (Endo) }\end{array}$ & $\begin{array}{l}\text { Post-burn } \\
\text { deformations } \\
\text { post- } \\
\text { traumatic } \\
\text { cicatricial } \\
\text { deformations }\end{array}$ & RCS & English & 356 (826) & $27(46)$ & $329(780)$ & $\begin{array}{l}\text { Expansion } \\
\text { duration } \\
100 \%\end{array}$ \\
\hline $\begin{array}{l}\text { Levi, } \\
\text { 2010, } \\
\text { USA }\end{array}$ & $\begin{array}{l}28 \text { (Open) } \\
41 \text { (Endo) }\end{array}$ & $15(100)$ & Burn breast & RCS & English & $13(33)$ & $6(16)$ & $7(17)$ & $\begin{array}{l}52 \\
\text { months } \\
86.7 \% \\
(13 / 15)\end{array}$ \\
\hline $\begin{array}{l}\text { Mi, } \\
\text { 2013, } \\
\text { China }\end{array}$ & 35.2 & $\begin{array}{l}68 \\
(53.1)\end{array}$ & Not specified & RCS & Chinese & $\begin{array}{l}128 \text { (Not } \\
\text { specified) }\end{array}$ & $\begin{array}{l}46 \text { (Not } \\
\text { specified) }\end{array}$ & $\begin{array}{l}82 \text { (Not } \\
\text { specified) }\end{array}$ & $\begin{array}{l}\text { Expansion } \\
\text { duration } \\
100 \%\end{array}$ \\
\hline $\begin{array}{l}\text { As'adi, } \\
2016, \\
\text { Iran }\end{array}$ & 27.2 & $\begin{array}{l}35 \\
(55.6)\end{array}$ & $\begin{array}{l}\text { Facial burn } \\
\text { scar }\end{array}$ & $\mathrm{RCT}$ & English & $63(81)$ & $32(43)$ & 31 (38) & $\begin{array}{l}16 \\
\text { months } \\
100 \%\end{array}$ \\
\hline $\begin{array}{l}\text { Yu, } \\
2016, \\
\text { China }\end{array}$ & $\begin{array}{l}\text { Not } \\
\text { calculated } \\
\text { (range, 6- } \\
26 \text { ) }\end{array}$ & $\begin{array}{l}29 \\
(41.2)\end{array}$ & $\begin{array}{l}\text { Microtia and } \\
\text { scar }\end{array}$ & RCS & Chinese & $\begin{array}{l}70 \text { (Not } \\
\text { specified) }\end{array}$ & $\begin{array}{l}35 \text { (Not } \\
\text { specified) }\end{array}$ & $\begin{array}{l}35 \text { (Not } \\
\text { specified) }\end{array}$ & $\begin{array}{l}\text { Expansion } \\
\text { duration } \\
\text { (Matched } \\
\text { cohort) }\end{array}$ \\
\hline $\begin{array}{l}\text { Huang, } \\
2017, \\
\text { China }\end{array}$ & $\begin{array}{l}32.5 \\
\text { (Open) } \\
30.5 \\
\text { (Endo) }\end{array}$ & $\begin{array}{l}28 \\
(46.7)\end{array}$ & $\begin{array}{l}\text { Scar, nevus, } \\
\text { hemangioma, } \\
\text { breast cancer }\end{array}$ & RCT & Chinese & $\begin{array}{l}60 \text { (Not } \\
\text { specified) }\end{array}$ & $\begin{array}{l}30 \text { (Not } \\
\text { specified) }\end{array}$ & $\begin{array}{l}30 \text { (Not } \\
\text { specified) }\end{array}$ & $\begin{array}{l}\text { Expansion } \\
\text { duration } \\
100 \%\end{array}$ \\
\hline
\end{tabular}

\section{Risk of Bias within Studies}

The Cochrane RoB tool showed unclear risk of bias in one RCT and high risk of bias in the other RCT (Fig. 2). The NOS showed low risk of bias ( $\geq 7$ stars) in all five cohort studies (Table 2). 
Table 2

Newcastle-Ottawa Quality Assessment of the Cohort Studies

\begin{tabular}{|llllll|}
\hline First Author, Year & Selection & Comparability & Outcome & Total & Quality \\
\hline Toranto 2007 & 4 stars & 1 stars & 3 stars & 8 stars & High \\
\hline Sharobaro 2008 & 4 stars & 1 stars & 3 stars & 8 stars & High \\
\hline Levi 2010 & 4 stars & 1 stars & 2 stars & 7 stars & High \\
\hline Mi 2013 & 3 stars & 1 stars & 3 stars & 7 stars & High \\
\hline Yu 2016 & 4 stars & 2 stars & 3 stars & 9 stars & High \\
\hline
\end{tabular}

\section{Synthesis of the Results}

The overall complication rate was significantly lower in patients receiving endoscopic expander placement than in those receiving open placement (pooled RD, $-0.28,95 \% \mathrm{Cl},-0.38$ to $-0.18, p<0.001$; Fig. 3). Furthermore, as Fig. 4 shows, endoscopic expander placement was associated with significantly shorter surgery time (WMD, -13.97 minutes; $95 \% \mathrm{Cl},-15.85$ to -12.08 minutes, $p<0.001$ ), shorter hospital stay (WMD, -16.88 hours; $95 \%$ Cl, -24.36 to -9.40 hours, $p<0.001$ ), and shorter time to full expansion (WMD, -27.53 days, $95 \%$ Cl, -38.82 to 16.24 days, $p<0.001)$. Notable heterogeneity was observed among studies evaluating total complications $(R=65 \%, p<0.001)$ and time to full expansion $(R=94 \%, p<0.001)$.

\section{Subgroup Analysis}

Subgroup analysis was performed by each complication. Z statistics for overall effect of haemotoma (RD, $-0.09 ; 95 \% \mathrm{Cl},-0.15$ to -0.03$)$, infection (RD, $-0.12 ; 95 \% \mathrm{Cl},-0.18$ to -0.05$)$, and dehiscence (RD, $-0.06 ; 95 \% \mathrm{Cl},-0.10$ to -0.03 ) exhibited significant differences at 2.89 ( $p$ $=0.004), 3.63(p<0.001)$, and $3.65(p<0.001)$, respectively. However, there were no statistically significant discrepancies in extrusion rate (RD, $-0.06 ; 95 \% \mathrm{Cl},-0.15$ to $0.03, p=0.200)$ and deflation rate $(\mathrm{RD}, 0.05 ; 95 \% \mathrm{Cl},-0.06$ to $0.17, p=0.360)$. The forest plots in Fig. 5 show the results of the subgroup analysis.

\section{Sensitivity analysis}

When the included studies were excluded one by one, all the point estimates were within the $95 \% \mathrm{Cl}$ of total pooled RD of total complications (Table 3), indicating the robustness of sensitivity.

Table 3

Sensitivity Analysis

\begin{tabular}{|llll|}
\hline Study Omitted & Risk Difference & $95 \%$ Cl & $R$ \\
\hline Toranto 2007 & -0.29 & $-0.40,-0.18$ & $70 \%$ \\
\hline Sharobaro 2008 & -0.28 & $-0.40,-0.15$ & $67 \%$ \\
\hline Levi 2010 & -0.24 & $-0.31,-0.17$ & $32 \%$ \\
\hline Mi 2013 & -0.31 & $-0.41,-0.21$ & $54 \%$ \\
\hline As'adi 2016 & -0.28 & $-0.40,-0.17$ & $70 \%$ \\
\hline Yu 2016 & -0.28 & $-0.39,-0.16$ & $70 \%$ \\
\hline Huang 2017 & -0.30 & $-0.41,-0.19$ & $67 \%$ \\
\hline
\end{tabular}

The funnel plot was symmetrical (if one study was disregarded), indicating no significant publication bias for total complications (Fig. 6). Furthermore, Egger's regression test ( $p=0.548$, Fig. 7) and Begg rank test $(p=0.401)$ further confirmed the absence of significant publication bias.

Meta-regression analysis of study characteristics did not show any associations affecting the calculated RD of total complications (Table 4), indicating that the heterogeneity of total complications came from other factors. 
Table 4

Results of Meta-Regression

\begin{tabular}{|lllll|}
\hline Variable & Coefficient & SE & $\boldsymbol{p}$ & $\mathbf{9 5 \%} \mathrm{Cl}$ \\
\hline Research type & -0.06 & 0.21 & 0.792 & $-0.72,0.60$ \\
\hline Article language & 0.11 & 0.25 & 0.677 & $-0.68,0.91$ \\
\hline Population of subjects & -0.04 & 0.30 & 0.905 & $-0.98,0.90$ \\
\hline SE, standard error & & & & \\
\hline
\end{tabular}

\section{Discussion}

In this article, we compared endoscopy-assisted expander placement with open tissue expander placement in plastic and reconstructive surgery and found that the endoscopic technique can lower the complication rate and shorten surgery time, hospital stay, and time to full expansion.

In the early 1990 s, plastic surgeons began using video-laparoscopy to aid placement of expanders. ${ }^{26,27}$ One way for establishing the cavity was facilitated by the continuous expansion and bulging by controlled injection of carbon dioxide ${ }^{27}$. Another way did not need the device of carbon dioxide insufflation. The special retractor with vertical and lateral movement was applied to keep the optical cavity open by separating the skin from the underlying fascia. ${ }^{10,28}$ Then, an endoscope (5-mm or $10-\mathrm{mm}$ diameter, and $0^{\circ}, 30^{\circ}$, or $45^{\circ}$ ) was inserted into the cavity and, under endoscopic vision, the plane of the area for placement of the expander was carefully dissected sharply or bluntly. ${ }^{29}$ Takeuchi et al. and Stephen et al. reported good results with a balloon dissector, with endoscopy used to facilitate extensive dissection through small incisions, especially in the trunk and limbs. ${ }^{30,31}$ After meticulous hemostasis, the expanders are placed in the specified area, and injected after a few days.

Endoscopic expander placement has been previously shown to lower risk of complications. ${ }^{8,11-16}$ In this meta-analysis, we demonstrated $28 \%$ lower pooled risk of complications after endoscopy-assisted expander placement than after traditional open expander placement. Subgroup analysis showed lower risk of haemotoma, infection, and dehiscence, which was probably mainly because of the precise hemostasis achieved under endoscopic visualization. ${ }^{11}$ In addition, the small remote incision used in the endoscopic technique reduces the possibility of cavity contamination by outside bacteria. Our previous study found that a haemotoma offers an ideal medium for bacterial proliferation and greatly increases the possibility of expander infection. ${ }^{32}$ Remote incision, far from the stress of the expansion, also minimizes the chances of wound dehiscence. $^{12}$

Whether the risks of extrusion and deflation can be reduced by the endoscopic technique remain controversial. ${ }^{11-13}$ Although the use of an endoscope reduces the length of surgical incision, the pockets for expander placement are not narrowed. According to our experience in expander placement by both the endoscopic method and the open method, appropriate and uniform dissection of the plane depends on the degree of exposure. In addition, it must be noted that the incidence of deflation is closely related to the quality of expander, with poor quality expanders being prone to damage and leakage of injection ports. ${ }^{11}$

In this study, surgery time, hospital stay, and time to full expansion were significantly shorter in patients receiving endoscopy-assisted expander placement. Some early studies reported that endoscopy-assisted expander placement requires a longer operative time, ${ }^{27,28}$ but this was disproved by later research that showed that the endoscopic technique could significantly shorten placement time, especially when more than one expander had to be placed. ${ }^{11-13,15}$ We believe that the contradictory conclusions were due to differences in the proficiency of the surgeons in endoscopic operation. The small and remote incision, and the earlier initiation of expansion, all contribute to shorten hospital stay and time to full expansion. Importantly, without complications to interfere with the process of expansion, fluid injection can be safely performed at an early stage.

The major advantages of endoscopy-assisted expander placement over open expander placement can be summarized as follows: 1) the endoscope allows the surgeon to dissect a wide area through a small, remote incision $\left.{ }^{28} ; 2\right)$ the risk of wound dehiscence is reduced ${ }^{33,34}$; 3 ) expansion can be initiated earlier and expansion duration can be shortened $33-35$; 4 ) appearance of subcutaneous hemorrhage can be closely monitored because of the clear, magnified visualization ${ }^{28}$; and 5) under direct vision, the dissection planes and blood vessels can be better recognized. ${ }^{36}$ The disadvantages are 1) the application of endoscopy calls for a video system, a light source, and extra surgical instruments, which increases costs 27 ; and 2 ) the surgeon needs to be specially trained in the procedure. ${ }^{27,28}$ 
The indications are similar for endoscopic tissue expander placement and for traditional open expander placement. ${ }^{26}$ However, previous reports and our own experience suggest that the endoscopy-assisted technique may be particularly suited for pediatric patients (because of less surgical trauma), ${ }^{37-40}$ for treatment in the facial or cervical region (because of the better hemostasis), ${ }^{13,33}$ and for treatment of cases requiring wide dissection (because of the better visualization). ${ }^{10,41,42}$

This study has some limitations. First, in our cohort, the main indications for expander placement were scar and breast reconstruction, which may be an important source of the pooled results' heterogeneity. Second, although we searched eight literature databases, the number of articles that met the eligibility criteria were relatively small, and only two were RCTs. However, the total number of patients was large and most studies were of good quality, with no evident publication bias.

\section{Conclusions}

Endoscopic placement of expanders may lower the risk of complications such as haemotoma, infection, and dehiscence and shorten surgery time, hospital stay, and time to full expansion. Further studies, preferably randomized clinical trials, are needed to confirm the benefits of endoscopy-assisted tissue expander placement.

\section{Declarations}

\section{Ethics approval and consent to participate}

Not applicable

\section{Consent for publication}

Not applicable

\section{Availability of data and materials}

Not applicable

Competing interests

The authors declare that they have no competing interests

\section{Funding}

Funding was received from the National Natural Science Foundation of China (81971851,81671925), Shaanxi Province Key R\&D Program Project (2018ZDXM-SF-081), and Discipline Promotion Project of Xijing Hospital (XJZT19D03).

\section{Authors' contributions}

CD performed the study design, collected and analysed the data, and wrote the draft. LD contributed to the conception of the study, helped data collection, and edited manuscript. ZY and XM contributed to designing study, providing administrative support, and editing the manuscript. All authors read and approved the final manuscript.

\section{Acknowledgments}

The first author thanks Qian He from Qujiang New Area Administrative Committee, Xi'an, China, for her support.

\section{References}

1. Connolly M, Ibrahim ZR, Johnson ON 3rd. Changing paradigms in lower extremity reconstruction in war-related injuries. Mil Med Res. 2016;3:9.

2. Ma X, Li Y, Li W, et al. Reconstruction of large postburn facial-scalp scars by expanded pedicled deltopectoral flap and random scalp flap: Technique improvements to enlarge the reconstructive territory. J Craniofac Surg. 2017;28(6):1526-1530.

3. Langdell HC, Taskindoust M, Levites HA et al. Systematic Review of Tissue Expansion: Utilization in Non-breast Applications .Plast Reconstr Surg Glob Open, 2021, 9: e3378.

4. Ogawa R. Surgery for scar revision and reduction: from primary closure to flap surgery. Burns Trauma. 2019;7:7. 
5. Neumann CG. The expansion of an area of skin by progressive distention of a subcutaneous balloon; use of the method for securing skin for subtotal reconstruction of the ear. Plast Reconstr Surg (1946). 1957;19(2):124-130.

6. Radovan C. Breast reconstruction after mastectomy using the temporary expander. Plast Reconstr Surg. 1982;69(2):195-208.

7. Austad ED, Rose GL. A self-inflating tissue expander. Plast Reconstr Surg. 1982;70(5):588-594.

8. Sharobaro VI, Moroz VY, Starkov YG, Yudenich AA. Treatment of post-burn scar deformations using tissue expansion and endoscopy. Ann Burns Fire Disasters. 2008;21(1):31-37.

9. Huang X, Qu X, Li Q. Risk factors for complications of tissue expansion: a 20-year systematic review and meta-analysis. Plast Reconstr Surg. 2011;128(3):787-797.

10. Serra JMR, Benito JR, Monner J, Zayuelas J, Párraga A. Tissue expansion with endoscopy. Ann Plast Surg. 1997;38(2):101.

11. Toranto JD, Yu D, Cederna PS. Endoscopic versus open tissue-expander placement: Is less invasive better. Plast Reconstr Surg. 2007;119(3):894.

12. Levi B, Brown DL, Cederna PS. A comparative analysis of tissue expander reconstruction of burned and unburned chest and breasts using endoscopic and open techniques. Plast Reconstr Surg. 2010;125(2):547.

13. As'adi K, Emami SA, Salehi SH, Shoar S. A Randomized Controlled Trial Comparing Endoscopic-Assisted Versus Open Neck Tissue Expander Placement in Reconstruction of Post-Burn Facial Scar Deformities. Aesthetic Plast Surg. 2016;40(4):526-534.

14. Mi Z, Gao Y, Zhang X, Yang X. Analysis of the complications of tissue expansion in face and neck. Health Must-read. 2013;12(4):165.

15. Yu B, Xiong M, Ma X. Observation on the effect of combined application of endoscope and light guide retractor under small incision in expander placement. Acta Universitatis Medicinalis Nanjing (Natural Science). 2016;36(9):1129-1131.

16. Clinical application analysis of skin soft tissue expander placement guided by endoscopy. Helongjiang Med J. 2017;41(7):653-654.

17. Higgins JP, Altman DG, Gøtzsche PC, et al. The Cochrane Collaboration's tool for assessing risk of bias in randomised trials. BMJ. 2011;343:d5928.

18. Deeks JJ, Dinnes J, D'Amico R, et al. Evaluating non-randomised intervention studies. Health Technol Assess. 2003;7(27):iii-x, 1-173.

19. Yuhara H, Steinmaus C, Cohen SE, Corley DA, Tei Y, Buffler PA. Is diabetes mellitus an independent risk factor for colon cancer and rectal cancer. Am J Gastroenterol. 2011;106(11):1911-1921; quiz 1922.

20. Higgins JP, Thompson SG, Deeks JJ, Altman DG. Measuring inconsistency in meta-analyses. BMJ. 2003;327(7414):557-560.

21. Wang Y, Tian J, Liu J. Suppressive Effect of Leukotriene Antagonists on Capsular Contracture in Patients Who Underwent Breast Surgery with Prosthesis: A Meta-Analysis. Plast Reconstr Surg. 2020;145(4):901-911.

22. Sterne JA, Egger M. Funnel plots for detecting bias in meta-analysis: guidelines on choice of axis. J Clin Epidemiol. 2001;54(10):10461055.

23. Egger M, Davey Smith G, Schneider M, Minder C. Bias in meta-analysis detected by a simple, graphical test. BMJ. 1997;315(7109):629634.

24. Begg CB, Mazumdar M. Operating characteristics of a rank correlation test for publication bias. Biometrics. 1994;50(4):1088-1101.

25. Athanasiou T, Al-Ruzzeh S, Kumar P, et al. Off-pump myocardial revascularization is associated with less incidence of stroke in elderly patients. Ann Thorac Surg. 2004;77(2):745-753.

26. Anger J, Szego T. Use of videoscopy as an aid in the placement of tissue expanders. Revista paulista de medicina. 1993;111(2):363-366.

27. Kobayashi S, Haramoto U, Takanashi M, Ohmori K. An endoscopic-assisted insertion of a tissue expander: Results in four cases. $J$ Plast Reconstr Surg. 1995;38(12):1257.

28. Serra JM. Retractor with mobile endoscope. Plast Reconstr Surg. 1997;100(2):529-531.

29. Egeland BM, Cederna PS. A minimally invasive approach to the placement of tissue expanders. Semin Plast Surg. 2008;22(1):9-17.

30. Takeuchi M, Nozaki M, Sasaki K, Isono N. Endoscopically assisted tissue expander insertion using balloon dissection. Br J Plast Surg. 1998;51(2):90.

31. Kovach SJ, Koger KE, Klitzman B, Germann G, Levin LS. Advantages of minimally invasive, balloon-dissector-assisted tissue expander placement: a clinical and experimental study. Ann Plast Surg. 2008;60(1):89-97.

32. Dong C, Zhu M, Huang L, et al. Risk factors for tissue expander infection in scar reconstruction: a retrospective cohort study of 2374 consecutive cases. Burns Trauma. 2020;8:tkaa037.

33. Elshaer WM, Enab AA, Elmanawi HM. Endoscopic tissue expansion placement in face and neck burn scar reconstruction. Burns. 2011;37(3):474.

34. Sharobaro VI, Moroz VY, Starkov YG, Strekalovsky VP. First experience of endoscopic implantation of tissue expanders in plastic and reconstructive surgery. Sur Endosc. 2004;18(3):513. 
35. Isono N, Nozaki M, Takeuchi M, Sasaki K. The Insertion of Tissue Expander with Endoscopic Assistance. J Plast Reconstr Surg. 2004;47(1):57.

36. Gu B, Li QF, Liu K, Shen GX. Curative effect of endoscopes-assited expander placement for scar treatment on breast. Chin J Clin Rehab. 2004;8(32):7338.

37. Burstein FD, Cohen SR, Huang MHS, Sims CA. Applications of endoscopic surgery in pediatric patients. Plast Reconstr Surg. 1998;102(5):1446.

38. Perlovaskaya VV, Sapukhin EV, Kozlov YA. The use of endovideosurgical technique for the treatment of children with major skin defects by expander dermotension. Detskaya khirurgiya. 2014;18(6):7-10.

39. Huang MHS, Cohen SR, Burstein FD, Simms CA. Endoscopic pediatric plastic surgery. Ann Plast Surg. 1997;38(1):1.

40. Paige KT, Eaves III FF, Wood RJ. Endoscopically assisted plastic surgical procedures in the pediatric patient. J Craniofac Surg. 1997;8(3):164.

41. Serra JMR, Benito JR, Monner J, Manzano M, Paloma V, Castro V. Reconstruction of pharyngostomes with a modified deltopectoral flap combining endoscopy and tissue expansion. Ann Plast Surg. 1998;41(3):283.

42. Ramakrishnan V, Southern SJ, Tzafetta R. Reconstruction of the high-risk chest wall with endoscopically assisted latissimus dorsi harvest and expander placement. Ann Plast Surg. 2000;44(3):250-258.

\section{Figures}

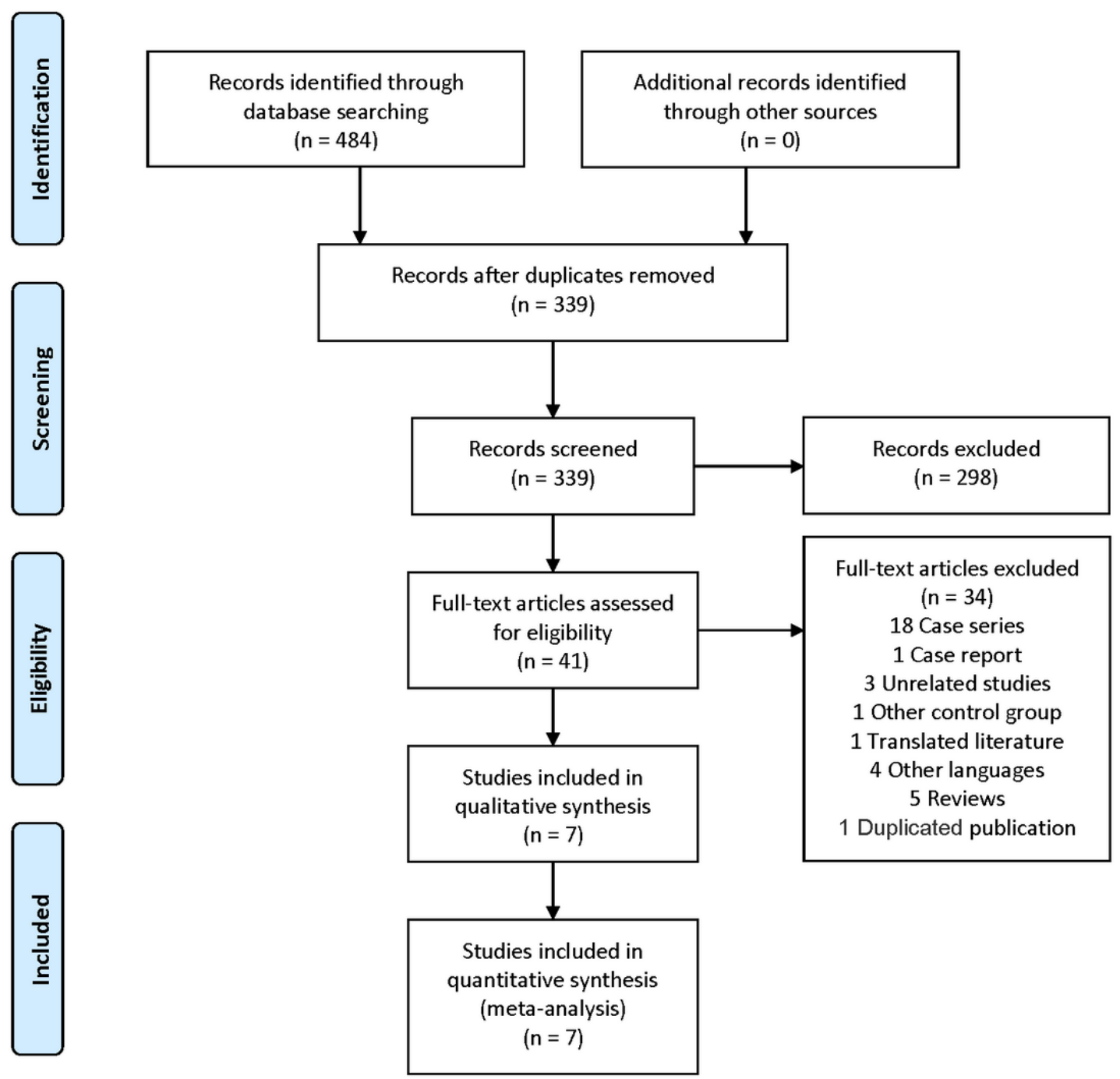

Figure 1 


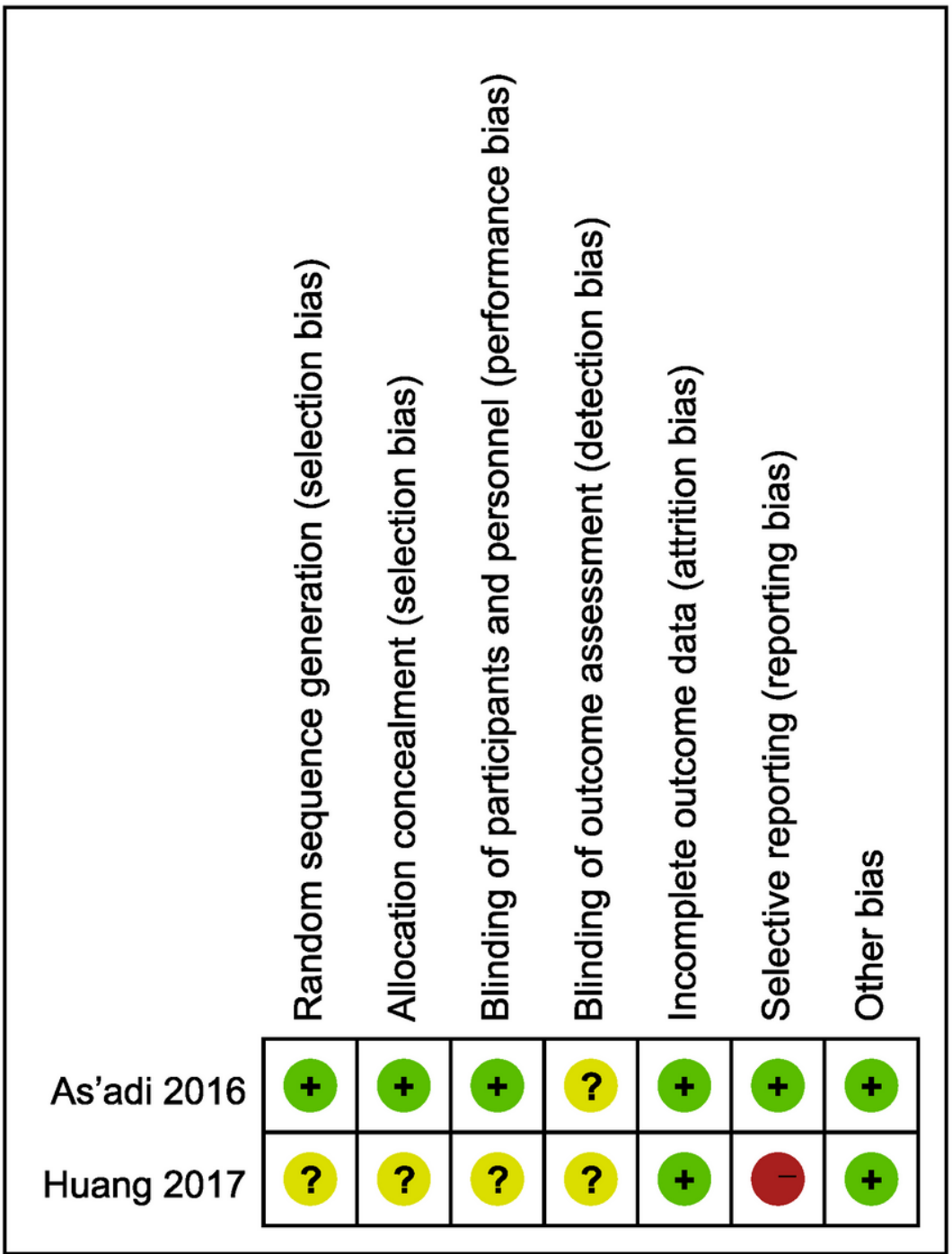

Figure 2

Risk of bias assessment for randomized controlled trials.

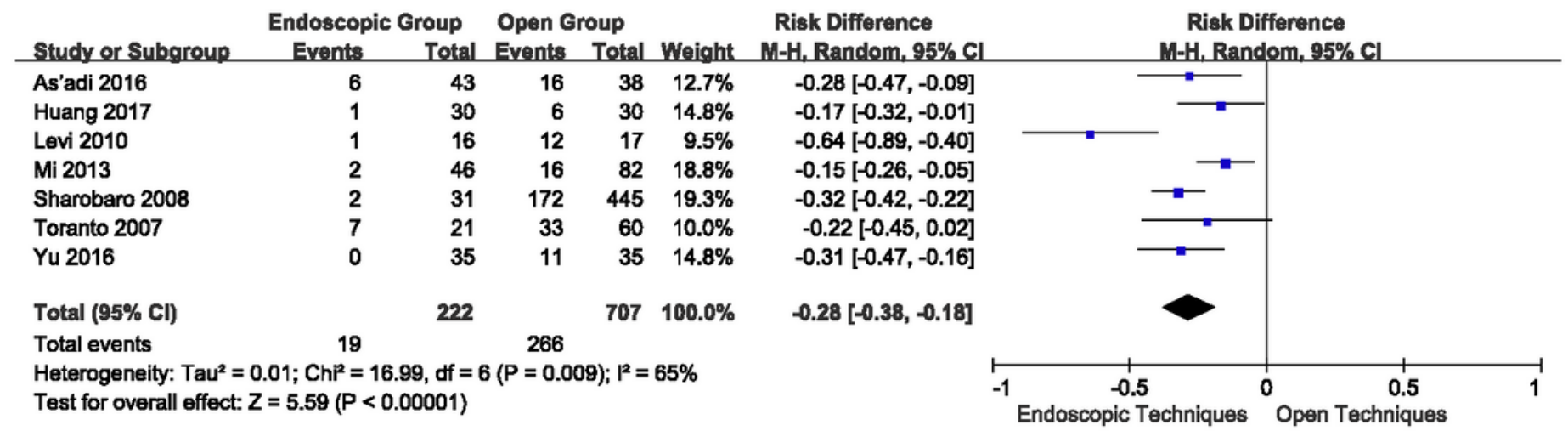

Figure 3 
Forest plot for overall complication.

1

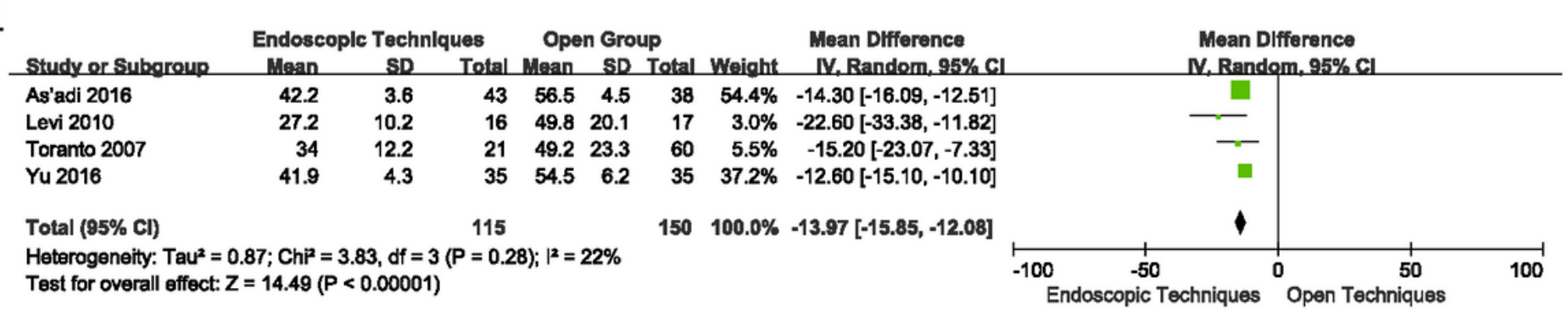

2

\begin{tabular}{|c|c|c|c|c|c|c|c|c|c|c|c|c|}
\hline \multirow[b]{2}{*}{ Study or Subgroup } & \multicolumn{3}{|c|}{ Endoscoplc Group } & \multicolumn{3}{|c|}{ Open Group } & & \multirow{2}{*}{$\begin{array}{l}\text { Mean Difference } \\
\text { M.Randem, } 95 \% \text { Cl }\end{array}$} & \multirow{2}{*}{\multicolumn{4}{|c|}{$\begin{array}{c}\text { Mean Difference } \\
\text { IV.Random, } 95 \% \mathrm{Cl}\end{array}$}} \\
\hline & Mean & SD & Total & Mean & SD & Total & Welght & & & & & \\
\hline As'adi 2016 & 7.4 & 4.5 & 43 & 26.3 & 7.7 & 38 & $60.7 \%$ & $-18.90[-21.69,-16.11]$ & & & & \\
\hline Levi 2010 & 5.76 & 16.8 & 16 & 10.32 & 26.4 & 17 & $18.1 \%$ & $-4.56[-19.57,10.45]$ & & & & \\
\hline Toranto 2007 & 12 & 21.6 & 21 & 33.6 & 38.4 & 60 & $21.2 \%$ & $-21.60[-35.01,-8.19]$ & & & & \\
\hline Total $(95 \% \mathrm{Cl})$ & & & 80 & & & 115 & $100.0 \%$ & $-16.88[-24.36,-9.40]$ & & & & \\
\hline $\begin{array}{l}\text { Heterogeneity: } \text { Tau }^{2}= \\
\text { Test for overall effect: }\end{array}$ & $\begin{array}{l}1.98 ; \mathrm{Cr} \\
=4.42\end{array}$ & $\begin{array}{l}=3.60 \\
<0.00\end{array}$ & $\begin{array}{l}d f=2( \\
\text { 01) }\end{array}$ & $(P=0.1$ & 17); $1^{2}=$ & $44 \%$ & & & $-100 \quad-50$ & Open Tech & $\begin{array}{l}50 \\
\text { nuques }\end{array}$ & 100 \\
\hline
\end{tabular}

\section{3}

\begin{tabular}{|c|c|c|c|c|c|c|c|c|c|c|c|}
\hline \multirow{2}{*}{$\begin{array}{l}\text { Study or Subgroup } \\
\text { As'adi } 2016\end{array}$} & \multicolumn{3}{|c|}{ Experimental } & \multicolumn{2}{|c|}{ Control } & Total & Weight & $\begin{array}{l}\text { Mean Difference } \\
\text { IV. Random, } 95 \% \text { CL }\end{array}$ & \multicolumn{3}{|c|}{$\begin{array}{l}\text { Mean Difference } \\
\text { M. Random. } 95 \% \text { CI }\end{array}$} \\
\hline & 93.5 & 10.2 & 43 & 112.1 & 14.2 & 38 & $37.9 \%$ & $-18.60[-24.05,-13.15]$ & - & & \\
\hline Levi 2010 & 92.59 & 21.2 & 16 & 121.56 & 29.2 & 17 & $21.0 \%$ & $-28.97[-46.31,-11.63]$ & & & \\
\hline Sharobaro 2008 & 33.6 & 35.9 & 31 & 71.8 & 12.8 & 442 & $27.3 \%$ & $-38.20[-50.89,-25.51]$ & 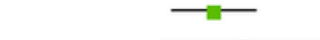 & & \\
\hline Toranto 2007 & 99.9 & 32.6 & 21 & 128.8 & 81.7 & 60 & $13.8 \%$ & $-28.90[-53.84,-3.96]$ & & & \\
\hline Total $(95 \% \mathrm{Cl})$ & & & 111 & & & 557 & $100.0 \%$ & $-27.54[-38.85,-16.24]$ & & & \\
\hline $\begin{array}{l}\text { Heterogeneity: } \mathrm{Tau}^{2}= \\
\text { Test for overall effect: }\end{array}$ & $\begin{array}{l}79.91 ; C \\
Z=4.78\end{array}$ & $\begin{array}{l}h i^{2}=8 \\
(P<0\end{array}$ & $\begin{array}{l}63, \mathrm{df}= \\
00001)\end{array}$ & $=3(\mathrm{P}$ & $0.03) ; 1$ & $1^{2}=65^{\circ}$ & & & $\begin{array}{ll}-100 & -50 \\
\text { Endoscopic Techniques }\end{array}$ & ${ }^{0}$ Open Techr & $\begin{array}{l}50 \\
\text { hiques }\end{array}$ \\
\hline
\end{tabular}

Figure 4

Forest plot for other outcomes. a, surgery time; b, hospital stay; c, time to full expansion. 


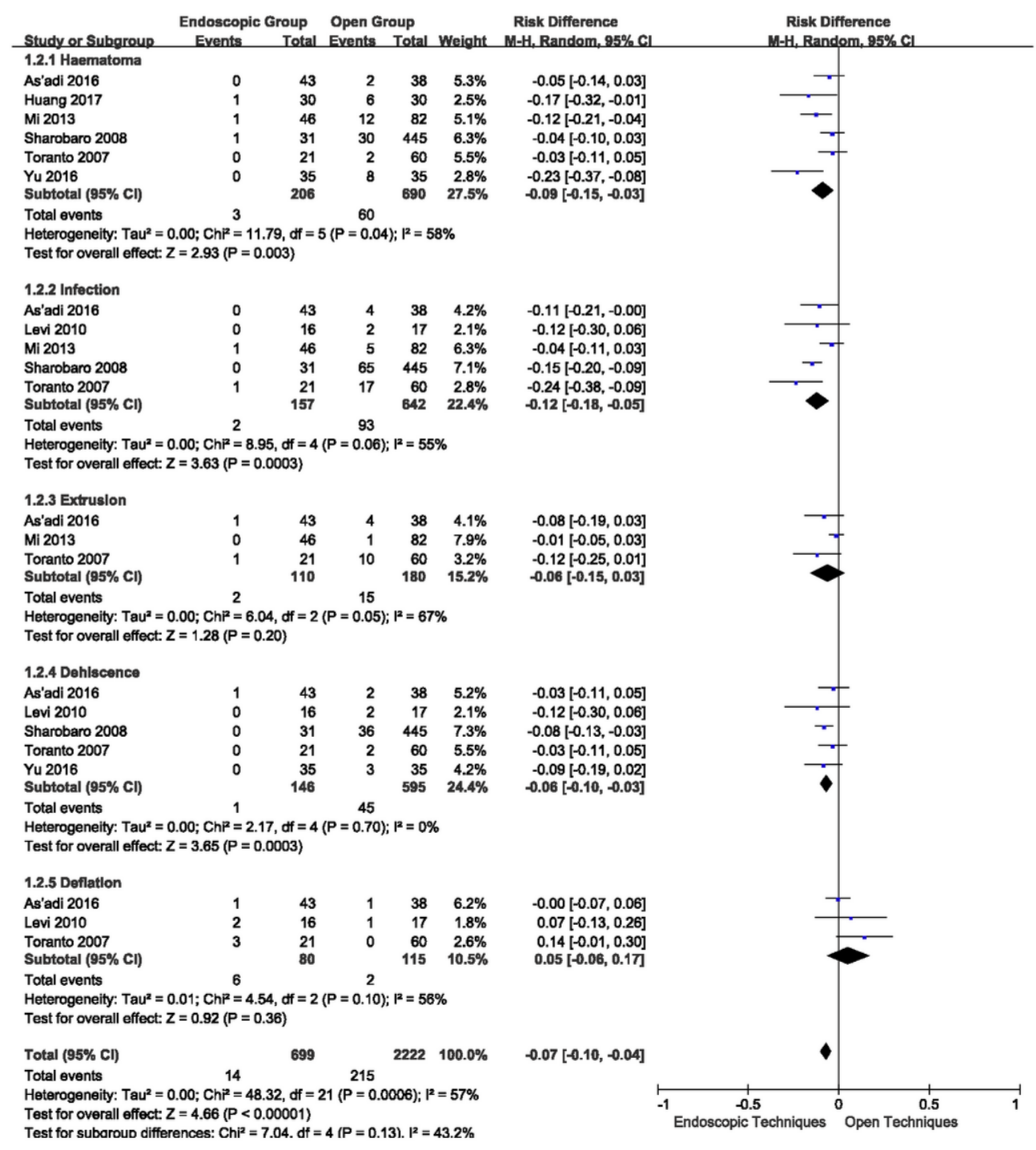

\section{Figure 5}

Forest plot for each complication (subgroup analysis). 


\section{Funnel plot with pseudo $95 \%$ confidence limits}

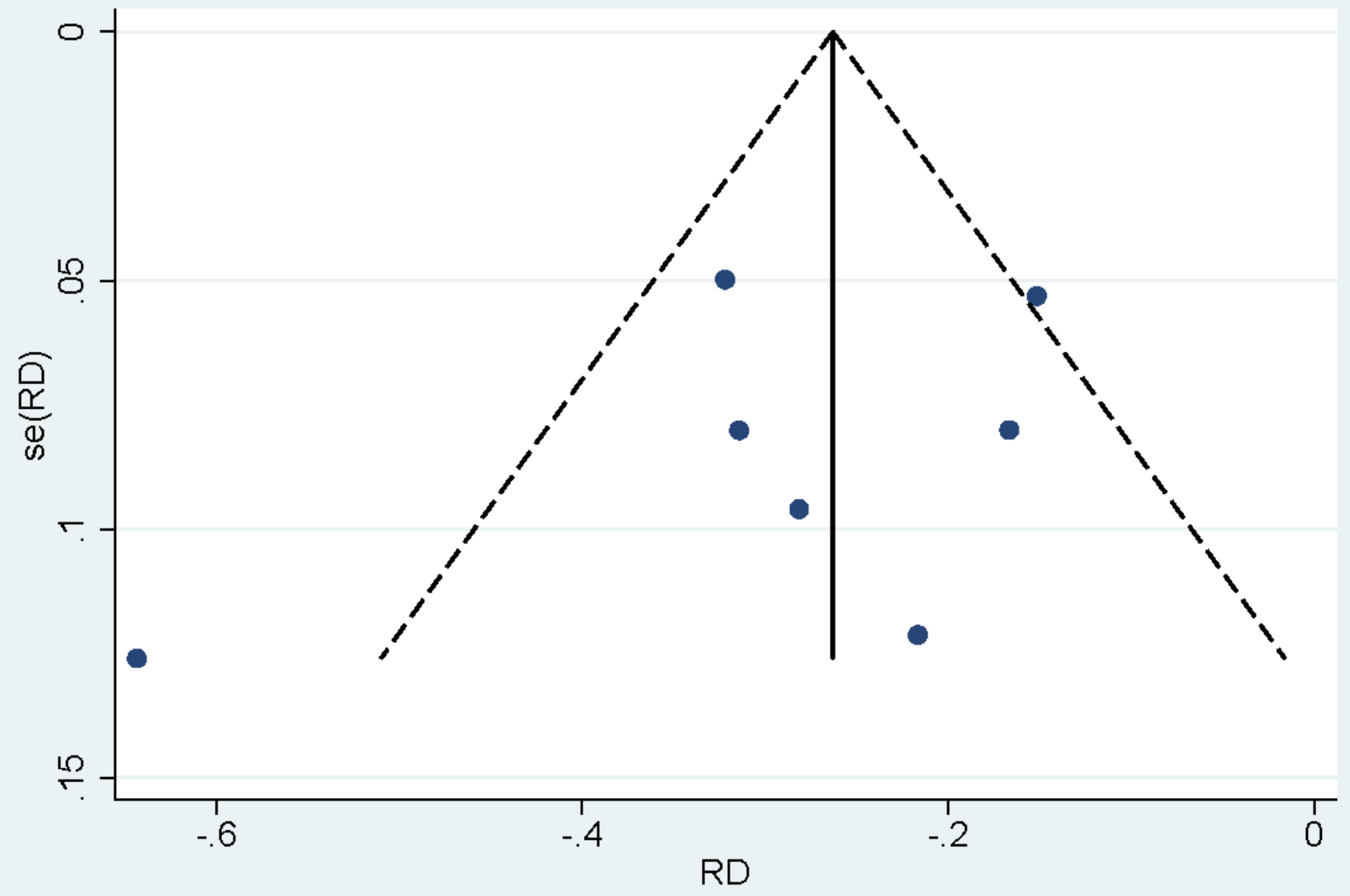

Figure 6

Funnel graph for assessing publication bias. SE, standard error; RD, risk difference. 


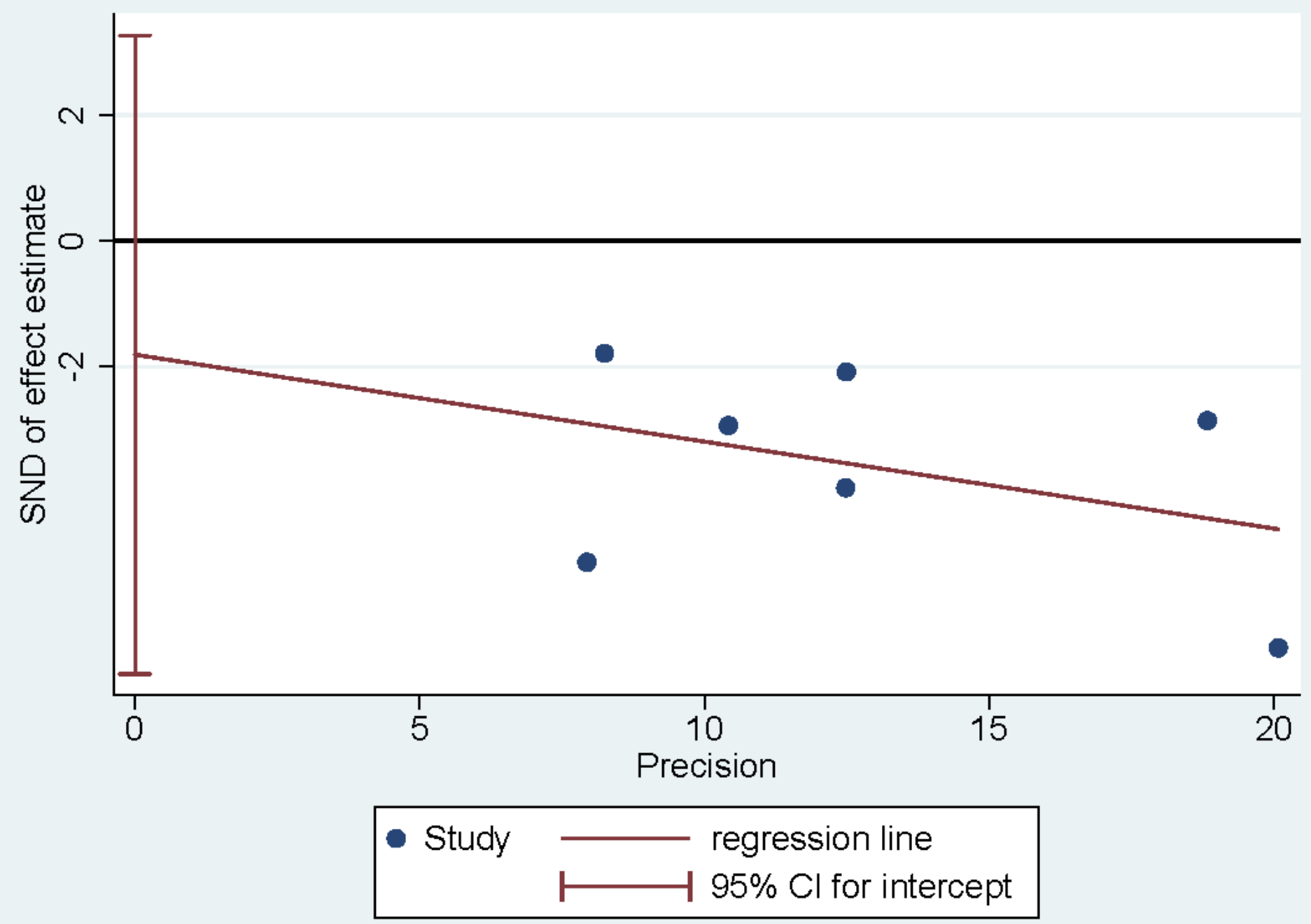

Figure 7

Egger funnel graph. SND, standard normal deviate; Cl, confidence interval.

\section{Supplementary Files}

This is a list of supplementary files associated with this preprint. Click to download.

- Supplement1Literaturesearchstrategy.docx 